\section{The frequency of wearing protective eyewear and face shield at educational hospital and public service Hospital in Makassar}

\author{
Rasmidar Samad, ${ }^{*}$ Ummul Rawiyah, Cisilia Septiany
}

Results: Number of operators at dental hospital Hasanuddin University who wore a protective eyewear were as many as 6 operators (5\%) and none of the operators wore face shields while working. While in PPKGM the number of operators who wore a protective eyewear were as much as 4 operators (19\%) and 11 operators (52\%) wore face shields while working.

Conclusion: The frequency of wearing protective eyewear and face shields at dental hospital Hasanuddin University is minimal and much lower than in PPKGM.
Department of Dental Public Health, Faculty of Dentistry, Hasanuddin University, Makassar, Indonesia

*Correspondence to: Rasmidar Samad, hscrp.samad@@gmail.com

Received: 19 April 2017

Revised: 27 May 2017

Accepted: 21 June 2017

Available online: 01 August 2017

Keywords: Infection control, Protective eyewear, Face shield, Dental Hospital Hasanuddin University, Dental and oral health service center Cite this Article: Samad R, Rawiyah U, Septiany C. 2017. The frequency of wearing protective eyewear and face shield at educational hospital and public service Hospital in Makassar. Journal of Dentomaxillofacial Science 2(2): 124-128. D0l:10.15562/jdmfs.v2i2.529

\section{Introduction}

Dental health workers are at very high risk of cross-infection with pathogenic microorganisms in the oral cavity and respiratory system such as human immunodeficiency virus (HIV), hepatitis B and C, Mycobacterium tuberculosis, streptococcus, staphylococcus and other bacteria and viruses. The risk of infection can be obtained from contact with blood, saliva, aerosols, or contaminated instruments while performing treatment in patients. Control infection procedures in dental practice include risky infectious disease vaccines such as Hepatitis B, instrument and work environments sterilization, raising universal precautions, applying infection control guidelines, and using personal protective equipment such as gloves, masks, protective eyewear and face shields, and using protective clothing while working. ${ }^{1-3}$

In Makassar, the cases of infectious diseases such as HIV, hepatitis, and tuberculosis (TB) increases every year. According to a data from the health office of Makassar, the prevalence of HIV in 2008 was 2.056 cases. In 2009 it reached 2.372 cases and in 2010 it was recorded 2.711 cases of HIV in Makassar. ${ }^{4}$ Due to increase in the prevalence of infectious disease in Makassar, dentist should pay special attention in order to get maximum self-protection and avoid cross-infection.

Dental hospital Hasanuddin University is an educational hospital for students at the Faculty of Dentistry Hasanuddin University. As an educational hospital, Dental Hospital Hasanuddin University should, of course, apply the standard operating procedures to both clinicians and residents when they provide treatment to their patients, including in this regard, particularly on the use of personal protective equipment.

In everyday observations conducted by previous researchers, the use of protective goggles and a face shield is usually done by both clinical and resident's patient in Dental Hospital Hasanuddin University. While in PPKGM, the use of protective eyewear and a face shield has been agreed upon by all dentists working in the hospital to serve as standard procedures when treating patients.

Based on the above, the researcher intends to conduct this research with the aim to know the comparison of the frequency of wearing protective eyewear and face shield at education clinic of Dental Hospital Hasanuddin University and in public service hospital of PPKGM in Makassar City. 


\section{Material and Methods}

The type of this research is a descriptive research. The study was conducted in March 2017 at Dental Hospital Hasanuddin University and at PPKGM in the department of periodontics and conservation. The subjects of the study were clinical student and resident at Dental Hospital Hasanuddin University and dentist in PPKGM. This research is done by doing direct observation on the subject of research. The data collected will be presented in the form of tables and graphs and analyzed descriptively.

\section{Results}

Table 1 shows the distribution of the number of clinical students, residents, dentists, and patients at Dental Hospital Hasanuddin University and PPKGM in Makassar. The total number of operators is 148 people with the largest percentage of clinical students that is 95 students $(64 \%)$. The total number of patients was 834 people and as many as 607 patients (72\%) were admitted to the PPKGM clinic.

Table 2 shows that in Dental Hospital Hasanuddin University operators who use protective eyewear while working only at Periodontics Department were as many as 6 operators (50\%). In PPKGM the

Table 1 Distribution of number of operators and patients at Dental Hospital Hasanuddin University and PPKGM

\begin{tabular}{lcc}
\hline \multirow{2}{*}{$\begin{array}{l}\text { Operator } \\
\text { Characteristics }\end{array}$} & Number of Operators & Number of Patients \\
\cline { 2 - 3 } Dental Hospital & $\mathbf{n}(\%)$ & $\mathbf{n}(\%)$ \\
Clinical Student & $95(64 \%)$ & $144(17.5 \%)$ \\
Resident & $32(22 \%)$ & $83(10.5 \%)$ \\
PPKGM & & \\
Dentist & $21(14 \%)$ & $607(72 \%)$ \\
Total & $148(100 \%)$ & $834(100 \%)$ \\
\hline
\end{tabular}

use of protective eyewear only at department of conservative was as many as 4 operators $(23.5 \%)$ and the use of face shields in department of periodontics was performed by all operators and 7 operators $(41.2 \%)$ in the department of conservative.

Figure 1 shows that in Dental Hospital Hasanuddin University the use of protective eyewear was very low i.e. only $5 \%$, there were no operators wearing face shield and $95 \%$ of operators did not use protective eyewear or face shields at work. At PPKGM those wearing a protective eyewear was $19 \%$, face shield was $52 \%$ and $29 \%$ of operators do not use protective eyewear or face shields at work.

Table 3 shows that in Dental Hospital Hasanuddin University the use of protective eyewear by the clinical students at department of periodontics was about $43 \%$. In PPKGM, the use of protective eyewear by dentists at department of conservative was $16 \%$, while the use of face shields by dentists at department of periodontics was $100 \%$ and in the department of conservative was 33\%.

Figure 2 shows that the percentage of operators who did not use protective equipment at Dental Hospital Hasanuddin University was very high at 96\% while in PPKGM was only $47 \%$. The use of protective eyewear at Dental Hospital Hasanuddin University was 4\% and 15\% in PPKGM. There were no operators who wore face shield at dental hospital Hasanuddin University while in PPKGM it was 38\%.

\section{Discussion}

Most of the clinical students and residents at Dental Hospital Hasanuddin University still have very little awareness in the use of protective eyewear. Some of them think that the use of protective eyewear is not needed. They consider the use of gloves and masks is sufficient as a self-protection to avoid cross-infection.

In addition, they noted that they feel uncomfortable wearing protective eyewear while working. It interferes their vision because some of the protective eyewear which they use are sometimes

Table 2 Frequency of distribution and percentage of wearing protective eyewear and face shield by operators at dental hospital Hasanuddin University and PPKGM $(\mathbf{n}=148)$

\begin{tabular}{|c|c|c|c|c|c|c|}
\hline \multirow[b]{3}{*}{ The tools used } & \multicolumn{4}{|c|}{ Dental Hospital Hasanuddin University } & \multirow{2}{*}{\multicolumn{2}{|c|}{$\begin{array}{l}\text { PPKGM } \\
\text { Dentist }\end{array}$}} \\
\hline & \multicolumn{2}{|c|}{ Clinical Student } & \multicolumn{2}{|c|}{ Resident } & & \\
\hline & $\begin{array}{c}\text { Periodontics } \\
\text { Department } \\
\text { n (\%) }\end{array}$ & $\begin{array}{c}\text { Conservative } \\
\text { Department } \\
\text { n (\%) }\end{array}$ & $\begin{array}{c}\text { Periodontics } \\
\text { PPDGS } \\
\text { n (\%) }\end{array}$ & $\begin{array}{c}\text { Conservative } \\
\text { PPDGS } \\
\text { n (\%) }\end{array}$ & $\begin{array}{c}\text { Periodontics } \\
\text { Department } \\
\text { n (\%) }\end{array}$ & $\begin{array}{c}\text { Conservative } \\
\text { Department } \\
\text { n (\%) }\end{array}$ \\
\hline Protective Eyewear & $6(50 \%)$ & 0 & 0 & 0 & 0 & $4(23.5 \%)$ \\
\hline Face Shield & 0 & 0 & 0 & 0 & $4(100 \%)$ & $7(41.2 \%)$ \\
\hline Not wearing & $6(50 \%)$ & $83(100 \%)$ & $13(100 \%)$ & $19(100 \%)$ & 0 & $6(35.3 \%)$ \\
\hline Total & $12(100 \%)$ & $83(100 \%)$ & $13(100 \%)$ & $19(100 \%)$ & $4(100 \%)$ & $17(100 \%)$ \\
\hline
\end{tabular}


condensed during working and the absence of hospital equipment is the reason for the resident. Another reason is that some operators who use personal glasses make these glasses as a substitute for protective eyewear, although the protection is inadequate.

This is similar to Rahman et al. ${ }^{2}$ who argued that the use of protective eyewear by clinical students in the United Arab Emirates was relatively low with a percentage of $30 \%,{ }^{2}$ as well as research by $\mathrm{Al}$-maweri

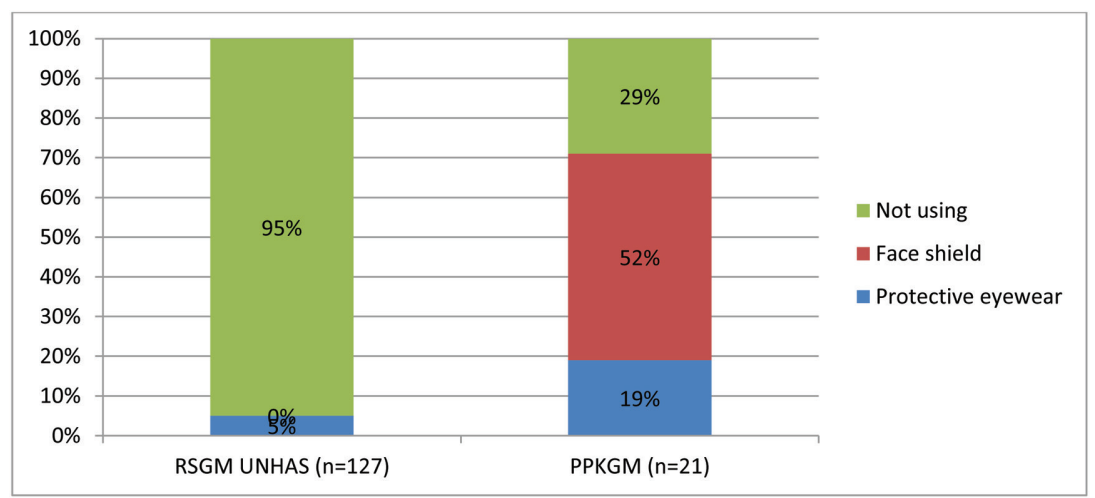

Figure 1 Total percentage of wearing protective eyewear and face shield by operators at Dental Hospital Hasanuddin University and PPKGM

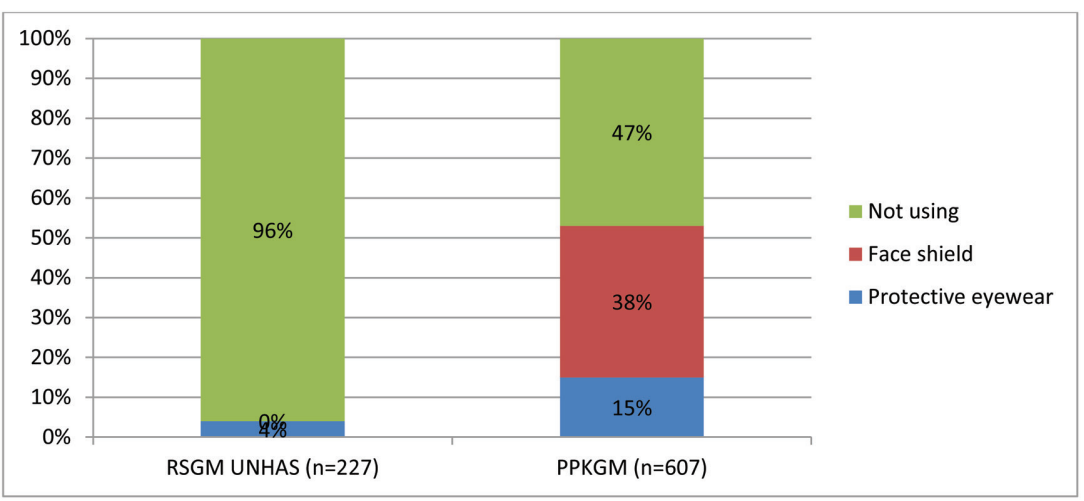

Figure 2 Total percentage of operator who wore protective eyewear and face shield based on the frequency of number of patient treated in Dental Hospital Hasanuddin University and PPKGM et al. ${ }^{3}$ showing that only $29.1 \%$ of dentistry students in Saudi Arabia used protective eyewear at work. ${ }^{3}$ Similarly, Bomireddy et al. ${ }^{5}$ said that the use of protective eyewear by dentists in India was very low at only $18.6 \% .^{5}$

The low frequency of using protective eyewear and face shields indicates low awareness by clinical student and dentists on the possibility of disease transmission through aerosols and blood splashes. ${ }^{3,6}$ However, on subjects who use protective eyewear when performing treatment is that the patient believes that the use of such protective equipment can give protection against blood splashes, saliva and other body fluids that have a potential risk of transmitting bacteria and viruses. The same was also stated by Laheij et al. ${ }^{7}$ regarding the importance of the use of protective eyewear when performing treatment in patients.

The use of protective eyewear when performing treatment in patients is strongly emphasized to avoid contamination of pathogenic bacteria and viruses from the patient's body fluids. Halboub et al. reported the presence of trauma or injuries occurring to the clinical students while performing treatment on the patient, among them caused by a scaler. The wound obtained from the scaler allows the transmission of pathogenic microorganisms, especially Hepatitis B and C or HIV. ${ }^{6}$

The frequency of using the face shield by clinical students and residents at dental hospital Hasanuddin University is also very low. Of the total operators in four parts of Dental Hospital Hasanuddin University, none of the operators use face shield equipment while working. This is consistent with some research results that reveal that the use of gloves and masks while working has become a regular habit by clinical students and dentists, but the use of protective goggles or face masks while working is still very minimal.

The data shows that in the UAE $99.2 \%$ of college students wear gloves, about $98.3 \%$ wear masks, but only $30 \%$ use protective eyewear or face shield at

Table 3 Frequency and percentage distribution of wearing protective eyewear and face shield by operators based on the frequency of number of patient treated in dental hospital Hasanuddin University and PPKGM $(\mathbf{n}=\mathbf{8 3 4})$

\begin{tabular}{|c|c|c|c|c|c|c|}
\hline \multirow[b]{3}{*}{ The tools used } & \multicolumn{4}{|c|}{ Dental Hospital Hasanuddin University } & \multirow{2}{*}{\multicolumn{2}{|c|}{$\begin{array}{l}\text { PPKGM } \\
\text { Dentist }\end{array}$}} \\
\hline & \multicolumn{2}{|c|}{ Clinical Student } & \multicolumn{2}{|c|}{ Resident } & & \\
\hline & $\begin{array}{c}\text { Periodontics } \\
\text { Department } \\
n(\%)\end{array}$ & $\begin{array}{c}\text { Conservative } \\
\text { Department } \\
\text { n (\%) }\end{array}$ & $\begin{array}{c}\text { Periodontics } \\
\text { PPDGS } \\
\text { n (\%) } \\
\end{array}$ & $\begin{array}{c}\text { Periodontics } \\
\text { Department } \\
\text { n (\%) }\end{array}$ & $\begin{array}{c}\text { Conservative } \\
\text { Department } \\
\text { n (\%) }\end{array}$ & $\begin{array}{c}\text { Periodontics } \\
\text { PPDGS } \\
\text { n (\%) } \\
\end{array}$ \\
\hline Protective Eyewear & $9(43 \%)$ & 0 & 0 & 0 & 0 & $92(16 \%)$ \\
\hline Face Shield & 0 & 0 & 0 & 0 & $45(100 \%)$ & $183(33 \%)$ \\
\hline Not wearing & $12(57 \%)$ & $123(100 \%)$ & $4(100 \%)$ & $79(100 \%)$ & 0 & $287(51 \%)$ \\
\hline Total & $21(100 \%)$ & $123(100 \%)$ & $4(100 \%)$ & $79(100 \%)$ & $45(100 \%)$ & $562(100 \%)$ \\
\hline
\end{tabular}


work. ${ }^{2}$ Also the results of research by Al-maweri et al. ${ }^{3}$ shows that dental students' compliance using gloves and masks while working has a high percentage of $98.5 \%$ and $90.8 \%$, but the use of protective eyewear or face shield is still low at only $29.1 \%{ }^{3}$ The same is also expressed by Bomireddy et al/ who suggested that the use of gloves by the dentist when working high enough is equal to $87.4 \%$, but the use of protective eyewear or face shield is still very low at only $18.6 \% .^{5}$ Anders PL et al. ${ }^{8}$ that the awareness of the importance of gloves is very high, but the use of protective eyewear and face shield is still very low. ${ }^{8}$

Based on the direct explanation by the operator, who said that most feel uncomfortable when using face shield because the tool sometimes reflects the blinding light, sometimes condensed, interferes with vision while working, and feels the face shield is too big to be used while giving treatment to the patient.

Overall, the lack of using protective eyewear and face shield by operators in educational clinics is also influenced by the less robust hospital policy of applying and controlling infection control standards particularly with regard to the use of personal protective equipment in the daily practice of clinical students and residents, and the absence of the provision of such protective equipment by Dental Hospital Hasanuddin University.

Different results were obtained on observations in PPKGM showing the percentage of dentists who used protective eyewear and face shield more than dentists who did not use protective equipment, meaning dentists knew the risk of crossinfection from the inputs or instructions given at department of conservative or department of periodontics.

The above results are consistent with the studies conducted by Yuzbasiouglu et al. ${ }^{1}$ which demonstrate excellent adherence to the use of protective eyewear while performing treatment in patients of $96.3 \%{ }^{1}$ Similarly a study by Anders et al. ${ }^{8}$ stated that the use of protective eyewear and face shields by clinical students in New York is quite high at $94 \%$ and $72.2 \%$ respectively. ${ }^{8}$ Similarly, Ebrahimpour et al. ${ }^{9}$ discloses that the percentage of protective eyewear used during treatment in patients is quite high at $74 \% .{ }^{9}$ Ibrahim $^{10}$ also revealed that as much as $54.7 \%$ of dentists use protective eyewear and face shield to protect themselves during the treatment procedure. ${ }^{10}$

The high awareness of dentists against the risk of cross-infection and the provision of protective equipment by the PPKGM management have a positive impact on dentist compliance in using protective eyewear and face shield, but there is no written operational standard so there are dentists who do not use protective eyewear or face shield while working. According to Ebrahimpour et al. ${ }^{9}$ the high adherence to the use of complete personal protective equipment by dental health workers is influenced by the regulation of infection control standards in each work environment. ${ }^{9}$

\section{Conclusion}

In the dental hospital Hasanuddin University educational clinic the frequency of using protective eyewear by clinical students is 5\% and there are no clinical or resident students who use face shield at work. While in the public service hospital PPKGM, frequency of using protective eyewear is at $19 \%$ and the use of face shield is at $52 \%$ by the dentist at work.

\section{Suggestion}

Suggestion for dental hospital Hasanuddin University is the use of protective eyewear and face shield by clinical and resident students as standard procedure for self-protection while doing treatment to the patient to prevent cross-infection. Also to the PPKGM, to further improve the supervision to the dentist related to the use of personal protective equipment while working where its use can be more maximized.

\section{Conflict of Interest}

The authors report no conflict of interest.

\section{References}

1. Yuzbasioglu E, Sarac D, Canbaz S, et al. A survey of cross-infection control procedures: knowledge and attitudes of Turkish dentist. J Appl Oral Sci 2009;17: 565569.

2. Rahman B, Abraham SB, Alsalami AM, et al. Attitudes and practices of infection control among senior dental student at college of dentistry, university of Sharjah in the United Arab Emirates. Eur J Dent 2013;7: 1-5.

3. Al-maweri S, Tarakji B, Shugaa-Addin B, et al. Infection control: knowledge and compliance among Saudi undergraduate dental student. GMS Hyg and Infect Control 2015;10: 1-8.

4. Data Dinas Kesehatan Kota Makassar, 2010

5. Bommireddy VS, Pachava S, Sanikommu S, et al. Infection control measure among dental practitioners in a Southern state of India: a cross-sectional study. Jiaphd 2016;14: 302-307.

6. Halboub ES, Al-maweri SA, Al-jamaei AA, et al. Knowledge, attitudes, and practice of infection control among dental student at Sana'a University, Yemen. Journal of International Oral Health 2015;7: 15- 19.

7. Laheij AMGA, Kistler JO, Belibasakis GN, et al. Health care associated viral and bacterial infections in dentistry. J Oral Microbiol 2012;4: 1-10. 
8. Anders PL, Townsend NE, Davis EL, et al. Observed infection control compliance in a dental school a natural experiment. Ajic 2016;44: e153-e156.

9. Ebrahimpour A, Pakravan AH, Nezhad MY, et al. Knowledge and performance of dental student with regard to infection control guidelines in dental school of Mazandaran University of Medical Science in 2015. Ijmrhs 2016;5: 298-304.

10. Ibrahim K. Cross-infection and infection control dentistry: knowledge, attitude and practice of patients attending dental clinics in King Abdulaziz University hospital. J Infection \& Public Health 2016;9: 1-4.

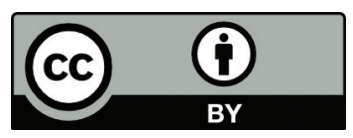

This work is licensed under a Creative Commons Attribution 